\title{
Hubungan Kadar Feritin Dengan Aktivitas Enzim SGOT Dan SGPT Pasien Thalasemia Di RSUD Abdul Moeloek Provinsi Lampung Tahun 2017
}

\author{
Dini Marifa Anggraini ${ }^{1}$, Sri Ujiani ${ }^{2}$ \\ ${ }^{1}$ Prodi Diploma IV Analis Kesehatan Politeknik Kesehatan Tanjungkarang \\ ${ }^{2}$ Jurusan Analis Kesehatan Politeknik Kesehatan Tanjungkarang
}

\begin{abstract}
Abstrak
Pasien thalasemia dengan transfusi reguler dapat terjadi penimbunan besi, yang dimonitor dengan pemeriksaan kadar feritin, dan dapat mengakibatkan terjadinya disfungsi organ-organ vital, termasuk organ hati. Penelitian ini bertujuan untuk mengetahui hubungan antara kadar feritin dengan fungsi hati yang dipantau melalui aktivitas enzim SGOT dan SGPT pada pasien thalasemia di RSUD dr. H. Abdul Moeloek Provinsi Lampung. Jenis penelitian merupakan analitik dengan desain cross sectional yang dilaksanakan pada bulan April-Mei 2017 di RSUD dr. H. Abdul Moeloek Provinsi Lampung. Subjek penelitian ini adalah pasien thalasemia yang mendapatkan transfusi darah secara rutin dan memiliki kadar feritin tinggi (>1000 ng/l). Kadar feritin sebagai variabel bebas diketahui melalui rekam medis pasien, aktivitas enzim SGOT dan SGPT diperiksa dengan metode IFCC. Data penelitian dianalisis dengan menggunakan korelasi Spearman, Odds Ratio, dan dituliskan dalam bentuk persamaan menggunakan regresi linier. Hasil penelitian menunjukkan sebanyak 32 pasien dengan kadar feritin di atas $1000 \mathrm{ng} / \mathrm{l}$ dan 11 pasien $(34,4 \%)$ diantaranya memiliki kadar feritin >1500 ng/ml. Sebanyak 18 pasien $(56,2 \%)$ memiliki aktivitas enzim SGOT tinggi dan 21 pasien $(65,6 \%)$ memiliki aktivitas enzim SGPT tinggi pula. Uji korelasi Spearman menunjukkan adanya hubungan positif kuat antara kadar feritin dengan aktivitas enzim SGOT ( $\mathrm{p}=0,000$ ), dengan nilai $\mathrm{OR}=6,000$ dan antara kadar feritin dengan aktivitas enzim SGPT $(P=0,001)$, dengan nilai $\mathrm{OR}=6,002$.
\end{abstract}

Kata Kunci : Enzim transaminase, feritin, thalasemia

\section{Correlation Of Feritin With Enzim The Activity of Enzymes SGOT And SGPT Patients Thalasemia In RSUD Abdul Moeloek Province Lampung 2017}

\begin{abstract}
Thalassemia patients with regular transfusions may have iron accumulation, monitored by examination of ferritin levels, and may result in the dysfunction of vital organs, including liver organ. This study aims to determine the relationship between ferritin levels and liver function monitored through SGOT and SGPT enzyme activity in thalassaemic patients in dr. H. Abdul Moeloek Lampung Province. This type of research is an analytical crosssectional design that was conducted in April-May 2017 in RSUD dr. H. Abdul Moeloek Lampung Province. The subjects of this study were thalassemia patients who received regular blood transfusions and had high ferritin levels (> $1000 \mathrm{ng} / \mathrm{l}$ ). The level of ferritin as the independent variable is known through the patient's medical record, the enzyme activity of SGOT and SGPT is examined by the IFCC method. Research data were analyzed by using Spearman correlation, Odds Ratio, and written in equation form using linear regression. The results showed that 32 patients with ferritin levels above $1000 \mathrm{ng} / \mathrm{l}$ and 11 patients (34.4\%) had ferritin levels> 1500 $\mathrm{ng} / \mathrm{ml}$. A total of 18 patients $(56.2 \%)$ had high SGOT enzyme activity and 21 patients $(65.6 \%)$ had high SGPT enzyme activity as well. Spearman correlation test showed a strong positive correlation between ferritin level and SGOT enzyme activity $(\mathrm{p}=0,000)$, with $\mathrm{OR}=6,000$ and between ferritin level and SGPT enzyme activity $(\mathrm{P}=0,001)$, with $\mathrm{OR}=6,002$.
\end{abstract}

Keywords: Transaminase enzyme, ferritin, thalassemia

Korespondensi : Sri Ujiani, Jurusan Analis Kesehatan Politeknik Kesehatan Tanjungkarang, Jl. Soekarno-Hatta No. 1 Bandar Lampung, mobile : 081540822571,e-mail : Sriujiani123@yahoo.com 


\section{Pendahuluan}

Thalasemia merupakan penyakit hemolitik kronik karena kelainan genetik yang diturunkan secara autosomal resesif.

Thalasemia memiliki karakteristik berupa penurunan atau pengurangan produksi rantai globin, sehingga menyebabkan eritrosit yang mudah rapuh, dan mengakibatkan anemia dengan berbagai macam derajatnya (Atmakusuma, 2014). Penyakit thalasemia dijelaskan pertama kali oleh Cooley (1925), semula ditemukan di sekitar Laut Tengah, menyebar sampai mediteran, Afrika, Timur Tengah, India, Asia Tenggara termasuk Indonesia (Permono dan Ugrasena, 2012). Berdasarkan manifestasi klinisnya thalasemia dibagi menjadi tiga kelompok yaitu thalasemia mayor yang membutuhkan transfusi darah seumur hidup, thalasemia minor tanpa gejala dan thalasemia intermedia (Bakta, 2013).

Pada tahun 2008 World Health Organization (WHO) menyatakan 4,5\% dari total penduduk dunia adalah pembawa sifat thalasemia dan meningkat menjadi $7 \%$ pada tahun 2011. Diperkirakan 400-500 ribu bayi thalassemia mayor lahir pertahun di seluruh dunia. Di Indonesia angka pembawa sifat thalassemia yakni 3-10\%. Berdasarkan data tersebut dan dengan memperhitungkan angka kelahiran serta jumlah penduduk Indonesia saat ini, diperkirakan akan lahir 3000 anak dengan thalasemia setiap tahun (Setiabudy dan Wahidiyat, 2010).

Berdasarkan data Komunitas Darah 4 Lampung yang terbentuk untuk mengumpulkan pendonor sukarela khusus untuk pasien thalasemia menyatakan jumlah pasien thalasemia di Provinsi Lampung hingga tahun 2013 sebanyak 92 orang. Sedangkan menurut data Dinas Kesehatan Provinsi Lampung tahun 2014 jumlah pasien thalasemia sebanyak 148 orang (Saputra, 2013).

Pasien thalasemia mendapatkan terapi berupa transfusi darah sebab pada pasien ini timbul manifestasi berupa anemia akibat ketidakmampuan tubuh untuk mengompensasi penurunan hemoglobin yang terjadi karena proses eritropoiesis tidak berjalan dengan efektif. Hal tersebut bila tidak ditangani dengan baik, dapat menyebabkan wajah pucat, hepatosplenomegali, keterlambatan pubertas, gangguan pertumbuhan serta ketidakmampuan untuk melakukan aktivitas sehari-hari (Permono dan Ugrasena, 2012).

Transfusi dilakukan secara kontinyu sebab thalasemia tidak dapat disembuhkan.
Sehingga pada pasien thalasemia yang mendapat transfusi reguler dapat terjadi hemokromatosis, yaitu penumpukan besi pada sel-sel parenkim, yang terjadi karena tubuh manusia mempunyai kemampuan yang terbatas dalam mengeliminasi kelebihan besi (Sulaiman, 2011).

Transfusi darah berulang dan peningkatan absorpsi besi di usus sebagai akibat eritropoiesis yang tidak efektif pada penderita thalassemia dan menyebabkan penimbunan besi. Pada keadaan penimbunan besi, kadar besi serum, saturasi transferin dan feritin akan meningkat serta total iron binding capacity (TIBC) terlampaui, hal ini dapat menyebabkan reaksi radikal bebas yang bersifat sitotoksik sehingga mengakibatkan kerusakan oksidasi lipid, protein dan asam nukleat.

Feritin merupakan indikator yang baik untuk menilai kelebihan besi pada thalasemia karena mudah dikerjakan, tersedia di banyak laboratorium dan mempunyai korelasi yang baik dengan temuan histologis biopsi hati. Penimbunan besi dapat diukur dengan menentukan kadar feritin serum karena paling mencerminkan status besi tubuh. Kadar feritin serum yang tinggi mencerminkan kadar besi plasma yang tinggi pula (Atmakusuma, 2014).

Pemeriksaan serum feritin untuk pasien thalasemia dilakukan secara teratur setidaknya 3 bulan sekali supaya memiliki nilai terapi dan prognostik. Jika serum feritin melebihi 1000 ng/l, maka pada keadaan ini dimulai terapi kelasi besi untuk menurunkan kadar besi dalam tubuh, sedangkan kadar feritin lebih dari atau sama dengan $1500 \mathrm{ng} / \mathrm{l}$ mengindikasikan kelebihan besi yang signifikan dan berhubungan dengan liver injury (Ikram dkk, 2014). Beberapa penelitian, seperti yang dilakukan oleh Aulia Fachri (2013) telah memaparkan gambaran kadar feritin dengan hasil pemeriksaan enzim hati.

Penumpukan besi ini dapat menyebabkan kerusakan jaringan dan kegagalan fungsi organ tubuh terutama hati, pankreas, jantung dan hipothalamus. Hati merupakan organ pertama yang terpengaruh, dimana $95 \%$ pasien dengan hemokromatosis mengalami hepatomegali, karena besi $(\mathrm{Fe})$ terkandung dalam setiap sel darah merah yang ditransfusikan. Semua racun atau senyawa-senyawa yang dapat berbahaya bagi tubuh akan menumpuk di hati (hepar) untuk didetoksifikasi. Dalam keadaan normal, setelah 120 hari sel darah merah akan mengalami apoptosis dan komponen-komponen penyusunnya akan diuraikan dan selanjutnya digunakan kembali untuk eritropoesis, besi $(\mathrm{Fe})$ 
yang dibebaskan dari proses tersebut dibawa ke dalam sistem retikuloendotelial/makrofag (hati, limpa, dan sumsum tulang) dan digunakan kembali untuk eritropoesis. Penumpukan besi (Fe) dalam hati menyebabkan timbulnya aktifitas oksigen atau radikal bebas. Radikal bebas inilah yang dapat merusak lapisan lemak dan protein pada membran dan organel sel hati, sehingga dapat menyebabkan nekrosis atau kebocoran membran sel hati (Sacher dan McPherson, 2012).

Pada pasien thalasemia terjadi penimbunan besi pada parenkim hati yang memungkinkan terjadinya cedera sel-sel hati. Uji fungsi hati yang sesuai untuk keadaan ini adalah pemeriksaan Gamma-Glutamyl Transferase (GGT), Serum GlutamicOxaloacetic Transaminase (SGOT), Serum Glutamic-Pyruvic Transaminase (SGPT) atau Lactate Dehydrogenase (LDH). Uji terhadap LDH bukan uji yang sensitif/spesifik untuk penyakit hati, begitu pula dengan GGT. Enzim GGT meningkat pada gangguan saluran empedu. SGOT dan SGPT merupakan enzim yang berpartisipasi dalam proses glukonenogenesis dengan mangkatalisasi perubahan asam amino dalam bentuk asam aspartat dan alanin menjadi asam ketoglutaric untuk memproduksi asam oksaloasetat dan asam piruvat. Kerusakan hepatoseluler dan kematian sel hati merupakan pemicu keluarnya enzim tersebut ke dalam sirkulasi. Enzim-enzim transaminase, merupakan petunjuk-petunjuk yang sensitif pada kerusakan hepatoseluler minimal sehingga bermanfaat untuk menemukan bentuk-bentuk penyakit hati tanpa ikterus (Nelson, 2012). Oleh karena itu pengukuran enzim SGOT dan SGPT lebih tepat digunakan dalam penelitian ini.

\section{Metode}

Jenis penelitian ini analitik, dengan desain cross sectional. Tujuan penelitian untuk menganalisis hubungan kadar feritin dan aktivitas enzim SGOT dan SGPT pasien thalasemia di RSUD Abdul Moeloek Provinsi Lampung. Subjek hanya diobservasi sekali dan pengukuran dilakukan terhadap variabel pada saat penelitian (Notoatmodjo, 2010).

Populasi pada penelitian yaitu seluruh pasien thalasemia di RSUD Abdul Moeloek Provinsi Lampung. Sampel yang digunakan diambil dari seluruh populasi dengan teknik purposive sampling menggunakan kriteria sebagai berikut :
1) Kriteria Inklusi: yaitu melakukan transfusi darah rutin selama penelitian dilakukan, kadar feritin lebih dari 1000 $\mathrm{ng} / \mathrm{ml}$, dan bersedia menjadi responden penelitian.

2) Kriteria Eksklusi:

a) Menderita salah satu dari beberapa penyakit hati selama kurun waktu penelitian (kerusakan hepatoseluler akut, infark miokard, kolaps sirkulasi, pankreatitis akut, mononukleosis infeksiosa, obstruksi saluran empedu, aritmia jantung, gagal jantung kongestif, tumor hati (metastasis atau primer), distrophia muscularis, perikarditis, sirosis, infark paru, delirium tremeus, cerebrovascular accident, hepatitis viral akut, nekrosis hati (toksisitas obat atau kimia), infeksi mononuklear, hepatitis kronis aktif, sumbatan empedu ekstra hepatik, sindrom Reye, pankreatitis, perlemakan hati, sirosis Laennec, sirosis biliaris).

b) Menderita demam tifoid.

c) Menderita demam dengue.

d) Tidak bersedia menjadi responden penelitian.

Data yang digunakan dalam penelitian ini adalah data primer dan data sekunder. Data primer diperoleh dengan melakukan pemeriksaan kadar SGOT dan SGPT pasien thalasemia dengan alat di Laboratorium Patologi Klinik RSUD Abdul Moeloek Provinsi Lampung. Metode pemeriksaan yang digunakan untuk pemeriksaan SGOT dan SGPT adalah IFCC-UV tanpa pengaktifan pyridoxal phospatase. Sedangkan data sekunder diperoleh dengan mencatat kadar feritin berdasarkan rekam medis pasien dari bagian Rekam Medis RSUD Abdul Moeloek Provinsi Lampung.

Hasil data yang diperoleh dan telah dikonfirmasi kemudian dianalisa dan digunakan untuk mengambil kesimpulan dari hasil penelitian.

1. Analisa Data

a. Analisa Univariat

Uji statisik normalitas yang akan digunakan dalam penelitian ini adalah uji Kolmogorov-Smirnov dengan proses komputerisasi. Metode uji ini dipilih sebab data yang didapatkan berskala numerik, sample dapat kurang dari atau lebih dari 30 dan data-data ini belum dikelompokkan 
dalam tabel frekuensi (Notoatmodjo, 2010).

b. Analisa Bivariat

Variabel terikat dan variabel bebas dianalisa menggunakan uji korelasi Pearson. Uji korelasi Spearman digunakan untuk menguji hubungan antara dua variabel dengan skala data interval atau rasio dengan data interval atau rasio yang memiliki distribusi data tidak normal. Hubungan antara variabel terikat dan variabel bebas, dengan uji korelasi Spearman, dapat ditetapkan sebagai hubungan positif atau negatif. Eratnya hubungan kedua variabel ini dinyatakan dengan koefisien korelasi.

Analisa berikutnya adalah dengan $O d d s$ Ratio, yaitu analisa yang digunakan untuk mencari tahu apakah variabel terikat merupakan faktor risiko untuk variabel bebas. Hubungan antara kedua variabel juga ditunjukkan dalam persamaan yang dirumuskan dengan analisa regresi linier. Baik pemasukan data maupun analisa dilakukan dengan proses komputerisasi (Notoatmodjo, 2010).

\section{Hasil}

Penelitian dilaksanakan di Rumah Sakit Umum Daerah dr. H. Abdul Moeloek Provinsi Lampung pada bulan Mei 2017 dengan mengambil data primer yaitu aktivitas enzim SGOT dan SGPT pasien thalasemia dan data sekunder yaitu kadar feritin pasien thalasemia berdasarkan rekam medik. Dari penelitian didapatkan 32 pasien yang memenuhi kriteria inklusi dan eksklusi sebagai subjek penelitian.

\section{Analisa Univariat}

Tabel 1. Profil Kadar Feritin, Aktivitas Enzim SGOTdan Aktivitas Enzim SGPT PasienThalasemia

\begin{tabular}{lccc}
\hline \multicolumn{1}{c}{ Variabel } & Rerata & Minimal & Maksimal \\
\hline Feritin (ng/ml) & 2096,87 & 1025,00 & 11800,00 \\
SGOT (U/I) & 60,81 & 14,00 & 476,00 \\
SGPT (U/l) & 51,06 & 10,00 & 295,00 \\
\hline
\end{tabular}

Sumber: Data Primer, 2017

Berdasarkan data dari tabel 1 didapatkan bahwa kadar feritin seluruh pasien telah mencapai $1000 \mathrm{ng} / \mathrm{ml}$ dengan rerata kadar feritin adalah 2096,87 ng/ml. Nilai terendah kadar feritin adalah $1025 \mathrm{ng} / \mathrm{ml}$ dan tertinggi $11800 \mathrm{ng} / \mathrm{ml}$.Aktivitas enzim SGOT memiliki nilai yang bervariasi dengan rerata $60,81 \mathrm{U} / \mathrm{l}$, nilai terendah $14 \mathrm{U} / \mathrm{l}$ dan nilai tertinggi mencapai 476 U/l. Aktivitas enzim SGPT memiliki rerata sebesar 51,06 U/1 dengan nilai terendah $10 \mathrm{U} / \mathrm{l}$ dan tertinggi $295 \mathrm{U} / \mathrm{l}$.

Tabel 2. Distribusi Kadar Feritin yang Dapat Menyebabkan Liver Injury

\begin{tabular}{c|c|c}
\hline Kadar Feritin & N & \% \\
\hline $1000-1500 \mathrm{ng} / \mathrm{ml}$ & 21 & 65,6 \\
$1500-11800 \mathrm{ng} / \mathrm{ml}$ & 11 & 34,4 \\
\hline Jumlah & 32 & 100 \\
\hline
\end{tabular}

Sumber: Data Primer, 2017

Jumlah pasien yang memiliki kadar feritin lebih dari atau sama dengan $1500 \mathrm{ng} / \mathrm{ml}$ yang dapat menyebabkan liver injury berdasarkan tabel di atas adalah 11 orang sedangkan 22 orang lainnya memiliki hasil pemeriksaan feritin yang belum mencapai 1500 $\mathrm{ng} / \mathrm{ml}$.

Tabel 3. Data Hasil Pemeriksaan Aktivitas Enzim SGOT dan SGPT

\begin{tabular}{lcccc}
\hline & \multicolumn{2}{c}{ SGOT } & \multicolumn{2}{c}{ SGPT } \\
\cline { 2 - 5 } & $\mathbf{N}$ & $\mathbf{\%}$ & N & \% \\
\hline Normal & 14 & 43,8 & 11 & 34,4 \\
Tinggi & 18 & 56,2 & 21 & 65,6 \\
\hline Jumlah & 32 & 100 & 32 & 100 \\
\hline
\end{tabular}

Sumber: Data Primer, 2017

Berdasakan tabel di atas, sebagian besar pasien memiliki aktivitas enzim SGOT tinggi sebanyak 18 orang $(56,3 \%)$ dan sisanya 14 orang $(43,8 \%)$ dengan aktivitas enzim SGOT normal. Hasil berikutnya menunjukkan terdapat 21 orang $(65,6 \%)$ memiliki aktiivitas enzim SGPT tinggi dan sebanyak 11 orang $(34,4 \%)$ memiliki aktivitas enzim SGPT normal.

\section{Analisa Bivariat}

Sebelum melakukan uji statistik pada penelitian ini, data variabel dependen dan independen harus dilakukan uji normalitas Kolmogorov-Smirnov. Pada uji KolmogorovSmirnov terhadap kadar feritin didapatkan nilai $\mathrm{p}=0,000(\mathrm{p}<0,05)$ menunjukkan bahwa distribusi data tidak normal. Uji KolmogorovSmirnov juga dilakukan terhadap aktivitas enzim SGOT dan SGPT, didapatkan nilai $\mathrm{p}=$ 0,000 dan $\mathrm{p}=0,000$. Hasil uji KolmogorovSmirnov menunjukkan bahwa sebaran data semua variabel tidak normal $(\mathrm{p}<0,05)$.

Selanjutnya dilakukan uji hipotesis untuk mengetahui korelasi kadar feritin dengan aktivitas enzim SGOT dan korelasi antara kadar feritin dengan kadar SGPT menggunakan uji korelasi Spearman karena variabel yang akan 
diuji merupakan data numerik (rasio) dan memiliki distribusi data tidak normal.

Tabel 4. Hubungan Kadar Feritin dengan Aktivitas Enzim SGOT dan SGPT

\begin{tabular}{lcc}
\hline & \multicolumn{2}{c}{ Kadar Feritin } \\
\cline { 2 - 3 } & P & \multicolumn{2}{c}{ Koefisien Korelasi } \\
\hline $\begin{array}{l}\text { Aktivitas } \\
\text { Enzim SGOT }\end{array}$ & 0,000 & 0,625 \\
\hline $\begin{array}{l}\text { Aktivitas } \\
\text { Enzim SGPT }\end{array}$ & 0,001 & 0,577 \\
\hline
\end{tabular}

Sumber: Data Primer, 2017

Pada uji korelasi Spearman didapatkan nilai $\mathrm{p}=0,000(\mathrm{p}<0,05)$ menunjukkan bahwa korelasi antara kadar feritin dengan aktivitas enzim SGOT adalah bermakna, nilai koefisien korelasi sebesar 0,625 menunjukkan bahwa arah korelasi positif dengan kekuatan korelasi yang kuat. Selain itu terdapat korelasi bermakna pula antara kadar feritin dengan aktivitas enzim SGPT yang ditunjukkan dengan nilai $\mathrm{p}=0,001$ ( $p<0,05$ ), nilai koefisien korelasi sebesar 0,577 menunjukkan bahwa arah korelasi positif dengan kekuatan korelasi yang sedang.

Setelah dilakukan uji korelasi, disimpulkan bahwa korelasi tersebut bemakna secara statistik. Selanjutnya hasil penelitian dibuat dalam bentuk persamaan garis lurus untuk menggambarkan secararinci korelasi antara kadar feritin dan aktivitas enzim SGOT dan SGPT serta dapat digunakan untuk memprediksi aktivitas enzim SGOT dan SGPT jika kadar feritin serum diketahui. Analisis statistik yang digunakan adalah regresi linier.

Dari hasil pengujian regresi linier antara kadar feritin dengan aktivitas enzim SGOT diperoleh nilai koefisien determinan ( $R$ square) $=0,036$ berarti 3,6 \% aktivitas enzim SGOT dapat dijelaskan oleh kadar feritin.

Tabel 5. Nilai Determinasi Kadar Feritin Terhadap Aktivitas Enzim SGOT Pasien Thalasemia di RSUD dr. H. Abdul Moeloek

\begin{tabular}{cccc}
\hline Model & R & R Square & Signifikansi \\
\hline 1 & 0,189 & 0,036 & 0,033 \\
\hline
\end{tabular}

Sumber: Data Primer, 2017

Nilai signifikansi yang ditampilkan adalah $0,033(\mathrm{p}<0,05)$ artinya persamaan garis yang diperoleh melalui analisis regresi linier bermakna secara statistik. Persamaan regresi diperoleh sebagai berikut:

Kadar SGOT $=45,531+0,007$ (Kadar Feritin)

Uji regresi linier antara kadar feritin dengan aktivitas enzim SGPT menunjukkan hasil nilai koefisien determinan ( $R$ Square $)=$ 0,067 berarti $6,7 \%$ aktivitas enzim SGPT dapat dijelaskan oleh kadar feritin.

Tabel 6. Nilai Determinasi Kadar Feritin Terhadap Aktivitas Enzim SGPT Pasien Thalasemia di RSUD dr. H. Abdul Moeloek

\begin{tabular}{cccc} 
Model & R & R Square & Signifikansi \\
\hline 1 & 0,260 & 0,067 & 0,010 \\
\hline \multicolumn{3}{r}{ Sumber: Data Primer, 2017}
\end{tabular}

Nilai signifikansi yang ditampilkan adalah $0,010(\mathrm{p}<0,05)$ artinya persamaan garis yang diperoleh melalui analisis regresi linier bermakna secara statistik. Persamaan regresi diperoleh sebagai berikut:

Kadar SGPT = 37,014 + 0,007 (Kadar Feritin)

Selanjutnya dilakukan analisis Odds Ratio terhadap kadar feritin dan aktivitas enzim SGOT dan SGPT untuk mengetahui apakah kadar feritin (variabel bebas) merupakan faktor resiko untuk aktivitas enzim SGOT dan SGPT (variabel terikat).

Tabel 7. Distribusi Kadar Feritin dengan Aktivitas Enzim SGOT Normal dan Tinggi

\begin{tabular}{ccccc} 
& \multicolumn{2}{c}{ Kadar SGOT } & & $\begin{array}{c}\mathbf{9 5 \%} \\
\text { Confidenc } \\
\text { Variabel }\end{array}$ \\
\cline { 2 - 3 } & $\begin{array}{c}\text { Tinggi } \\
\mathbf{n}(\%)\end{array}$ & $\begin{array}{c}\text { Normal } \\
\mathbf{n}(\%)\end{array}$ & & \\
\hline $\begin{array}{c}\text { Kadar Feritin } \\
<1500 \mathrm{ng} / \mathrm{ml}\end{array}$ & $9(28,1 \%)$ & $12(37,5 \%)$ & & \\
$>1500 \mathrm{ng} / \mathrm{ml}$ & $9(28,1 \%)$ & $2(6,2 \%)$ & 6.000 & $1,0-34,8$
\end{tabular}

Berdasarkan tabel 7. didapatkan hasil $\mathrm{OR}=6,000$ dan $95 \% \mathrm{CI}=1,0-34,8$. Hasil ini menunjukkan bahwa OR >1, artinya kadar feritin merupakan salah satu faktor resiko tingginya aktivitas enzim SGOT dalam pemeriksaan uji fungsi hati.

Tabel 8. Distribusi Kadar Feritin dengan Aktivitas Enzim SGPT Normal dan Tinggi

\begin{tabular}{ccccc}
\multirow{2}{*}{ Variabel } & \multicolumn{2}{c}{ Kadar SGPT } & \multicolumn{1}{c}{$\begin{array}{c}\mathbf{9 5 \%} \\
\text { Or }\end{array}$} \\
\cline { 2 - 3 } & $\begin{array}{c}\text { Tinggi } \\
\mathbf{n}(\%)\end{array}$ & $\begin{array}{c}\text { Normal } \\
\mathbf{n}(\%)\end{array}$ & $\begin{array}{c}\text { Interval } \\
\text { Intidence }\end{array}$ \\
\hline $\begin{array}{c}\text { Kadar Feritin } \\
<1500 \mathrm{ng} / \mathrm{ml}\end{array}$ & $10(31,2 \%)$ & $11(34,3 \%)$ & & \\
\hline $1500 \mathrm{ng} / \mathrm{ml}$ & $11(34,3 \%)$ & 0 & 6,022 & $1,1-35,2$ \\
\hline
\end{tabular}

Sumber: Data Primer, 2017

Berdasarkan tabel 8. didapatkan hasil OR $=6,022$ dan $95 \% \mathrm{CI}=1,1-35,2$. Hasil ini 
menunjukkan bahwa OR > 1 , artinya kadar feritin merupakan salah satu faktor resiko tingginya aktivitas enzim SGPT dalam pemeriksaan uji fungsi hati.

\section{Pembahasan}

Thalasemia merupakan penyakit keturunan yang ditandai dengan anemia kronis akibat hemoglobinopati sehingga membutuhkan penatalaksanaan berupa transfusi darah reguler. Dalam penelitian yang telah dilaksanakan di RSUD dr. H. Abdul Moeloek pada bulan Mei 2017 seluruh sampel telah menerima transfusi darah reguler dengan kadar feritin mencapai lebih dari 1000 ng/ml. Hasil ini sesuai dengan data kuisioner yang menunjukkan bahwa pasien telah mendapatkan terapi tranfusi darah secara rutin selama lebih dari 1 tahun.

Pada keadaan serum feritin melebihi $1000 \mathrm{ng} / \mathrm{ml}$, menurut Ikram, dkk (2014), terapi kelasi besi mulai diberikan kepada pasien. Berdasarkan teori tersebut, hanya 2 orang subjek penelitian yang rutin mengonsumsi obat kelasi besi, 30 orang lainnya tidak mengonsumsi obat kelasi secara rutin.

Penimbunan besi yang bersifat kronik mengakibatkan transferin telah jenuh oleh besi sehingga besi ini muncul dalam bentuk NonTransferin Bound Iron (NTBI). Sebanyak 70\% dari NTBI ini mengalami ambilan yang cepat oleh hati, dengan kata lain, hati merupakan organ pertama yang terpengaruh oleh keadaan penimbunan besi pada thalasemia (Kartoyo dan Purnamawati, 2013). Pemeriksaan aktivitas enzim SGOT dan SGPT dapat menunjukkan keadaan fungsi hati pada keadaan ini. Dari hasil penelitian didapatkan 14 orang $(43,8 \%)$ memiliki hasil pemeriksaan aktivitas enzim SGOT normal dan 18 orang $(56,2 \%)$ lainnya tinggi. Hasil pemeriksaan aktivitas enzim SGPT pada 11 orang $(34,4 \%)$ normal sedangkan pada 21 orang $(65,6 \%)$ lainnya tinggi.

Ikram, dkk (2014) menyebutkan bahwa kadar feritin $\geq 1500 \mathrm{ng} / \mathrm{ml}$ mengindikasikan kelebihan besi yang signifikan dan berhubungan dengan liver injury. Dalam penelitian ini didapatkan sebanyak 11 orang $(34,4 \%)$ memiliki kadar feritin lebih dari 1500 $\mathrm{ng} / \mathrm{ml}$ sedangkan 21 orang $(65,6 \%)$ lainnya memiliki kadar feritin yang belum mencapai $1500 \mathrm{ng} / \mathrm{ml}$. Hal ini menunjukkan bahwa sebagian kecil sampel beresiko mengalami liver injury yang dapat dilihat dari hasil pemeriksaan aktivitas enzim SGOT dan SGPT. Dari hasil penelitian menunjukkan bahwa dari 11 orang yang memiliki kadar feritin tinggi 9 orang $(81,8 \%)$ diantaranya memiliki aktivitas enzim SGOT tinggi dan 11 orang (100\%) memiliki aktivitas enzim SGPT tinggi pula. Sementara sampel lainnya memiliki aktivitas enzim SGOT dan SGPT normal. Sementara itu, dari 21 orang yang memiliki kadar feritin $<1500 \mathrm{ng} / \mathrm{ml}, 9$ orang $(42,8 \%)$ memiliki aktivitas enzim SGOT dan SGPT tinggi sedangkan 12 orang $(57,1 \%)$ lainnya normal.

Setelah dilakukan uji korelasi Spearman antara kadar feritin dengan aktivitas enzim SGOT didapatkan nilai $\mathrm{p}=0,000(\mathrm{p}<0,05)$ menunjukkan bahwa ada korelasi yang bermakna antara kadar feritin dengan aktivitas enzim SGOT, nilai koefisien korelasi sebesar 0,625 menunjukkan bahwa arah korelasi positif dengan kekuatan korelasi yang kuat. Selain itu terdapat korelasi bermakna pula antara kadar feritin dengan aktivitas enzim SGPT yang ditunjukkan dengan nilai $\mathrm{p}=0,001(\mathrm{p}<0,05)$, nilai koefisien korelasi sebesar 0,577 menunjukkan bahwa arah korelasi positif dengan kekuatan korelasi yang sedang. Hasil uji korelasi Spearman ini menunjukkan bahwa terdapat hubungan antara kadar feritin dengan aktivitas enzim SGOT dan SGPT.

Korelasi antara kadar feritin dengan aktivitas enzim SGOT dan SGPT didukung pula oleh hasil perhitungan OR antara kadar feritin dengan aktivitas enzim SGOT dan SGPT yaitu OR > 1, artinya kadar feritin merupakan salah satu faktor resiko meningkatnya aktivitas enzim SGOT dan SGPT dalam pemeriksaan uji fungsi hati pada pasien thalasemia. Kadar feritin yang mencapai $1500 \mathrm{ng} / \mathrm{ml}$ menunjukkan penimbunan besi yang signifikan dan memiliki resiko lebih besar untuk terjadinya cedera sel hati (liver injury). Hal ini sesuai dengan teori yang telah diungkapkan oleh Ikram, dkk (2014) melalui penelitian observasional analitik sebelumnya.

Peningkatan produksi enzim-enzim transaminase yaitu SGOT dan SGPT terjadi sebagai respon terhadap keadaan cedera sel-sel hati. Mekanisme cedera sel hati pada pasien thalasemia dengan transfusi reguler diawali dengan penimbunan besi yang terjadi akibat eritropoesis yang inefektif, peningkatan absorpsi besi pada sistem gastrointestinal, penurunan mekanisme fisiologis tubuh dalam mengekskresikan besi dan yang paling utama adalah akibat transfusi darah berulang. Satu unit sel darah merah yang ditransfusikan mengandung sekitar $250 \mathrm{mg}$ besi sementara tubuh tidak dapat membuang lebih dari $1 \mathrm{mg}$ besi setiap harinya. Keadaan penimbunan besi 
pada penelitian ini diukur dengan menggunakan pemeriksaan kadar feritin. Feritin adalah protein pengikat besi yang berperan sebagai penyimpan besi primer, dengan demikian feritin mempunyai hubungan erat dengan tingkat besi dalam tubuh. Sebagian kecil feritin terdapat pada serum manusia dan dapat meningkat pada keadaan kelebihan besi dan adanya proses inflamasi atau kerusakan jaringan (Frank dan Suzy, 2002).

Hati, pada keadaan penimbunan besi akan melakukan ambilan NTBI yang bersama dengan fero yang dilepaskan oleh feritin membetuk senyawa hidroksi radikal melalui reaksi fenton. Senyawa hidroksi radikal ini menyebabkan peroksidasi lipid yang diikuti dengan tebentuknya produk peroksida yang reaktif dan bersifat toksik. Struktur membran sel hati pun mengalami perubahan sehingga membran sel rusak dan fungsi organel terganggu. Keadaan cedera/kerusakan sel hati ini dapat pula diikuti dengan kematian sel hati. Enzim-enzim transaminase, yang diperiksa dalam penelitian ini merupakan petunjuk yang sensitif pada kerusakan hepatoseluler minimal sehingga bermanfaat untuk menemukan bentukbentuk penyakit hati (Nelson, 2012).

Adanya hubungan antara kadar feritin dengan aktivitas enzim SGOT dan SGPT menunjukkan bahwa pemantauan aktivitas enzim SGOT dan SGPT, selain untuk mengetahui kondisi hati, juga dapat dipertimbangkan sebagai alternatif pemantauan kadar feritin pada pasien thalasemia. Hal ini didasarkan pada konsep cost effective dimana pemeriksaan kadar feritin membutuhkan biaya lebih besar jika dibandingkan dengan pemeriksaan aktivitas enzim SGOT dan SGPT. Dengan memeriksa aktivitas enzim SGOT dan SGPT dapat diketahui estimasi kadar feritin dalam tubuh pasien thalasemia sehingga dapat dilakukan pencegahan komplikasi penimbunan besi pada organ vital lain.

berikut:

Simpulan hasil penelitian sebagai

1. Dari 32 sampel pasien thalasemia didapatkan rata-rata kadar feritin 2096,87 $\mathrm{ng} / \mathrm{ml}$, dengan nilai terendah $1025 \mathrm{ng} / \mathrm{ml}$ dan tertinggi mencapai $11800 \mathrm{ng} / \mathrm{ml}$.

2. Dari 32 sampel pasien thalasemia didapatkan rata-rata aktivitas enzim SGOT 60, $81 \mathrm{U} / \mathrm{l}$, dengan nilai terendah $14,0 \mathrm{U} / 1$ dan tertinggi $476 \mathrm{U} / \mathrm{l}$.

3. Dari 32 sampel pasien thalasemia didapatkan rata-rata aktivitas enzim SGPT $51,06 \mathrm{U} / \mathrm{l}$, dengan nilai terendah 10,0 U/1 dan tertinggi $295 \mathrm{U} / \mathrm{l}$.
4. Ada hubungan positif yang kuat antara kadar feritin dengan aktivitas enzim SGOT dan SGPT pada pasien thalasemia di RSUD dr. H. Abdul Moeloek Provinsi Lampung.

\section{Daftar Pustaka}

1. Atmakusuma, D 2014, Thalassemia: Manifestasi Klinis, Pendekatan Diagnosis, dan Thalassemia Intermedia. Dalam: Buku Ajar Ilmu Penyakit Dalam. Jilid II. Edisi VI, Pusat Penerbitan Departemen Ilmu Penyakit Dalam FakultasKedokteran Universitas Indonesia, Jakarta.

2. Atmakusuma, D dan Setyaningsih, I 2014, Dasar-dasar Thalassemia: Salah Satu Jenis Hemoglobinopati. Dalam: Buku Ajar Ilmu Penyakit Dalam. Jilid II.Edisi VI, Pusat Penerbitan Departemen Ilmu Penyakit Dalam FakultasKedokteran UniversitasIndonesia, Jakarta.

3. Bain, BJ 2015, Hematologi Kurikulum Inti, EGC, Jakarta.

4. Bakta, IM 2013, Hematologi Klinik Ringkas, EGC, Jakarta..

5. Dinas Kesehatan Provinsi Lampung 2014, Profil Kesehatan Lampung, Lampung.

6. Frances, KW, Alih Bahasa : S. Boedina Kresno dkk. 2011, Tinjauan Klinis Atas Hasil Pemeriksaan Laboratorium, edisi 9, cetakan ke-1, EGC, Jakarta

7. Gandasoebrata, R 2012, Penuntun Laboratorium Klinik, Edisi 16, Dian Rakyat, Jakarta.

8. Gaw, A, dkk 2012, Biokimia Klinis, EGC, Jakarta.

9. Giardina, PJ dan Grady, RS 2012, Thalassemia syndromes. In: Hematology : BasicPrinciple and Practice. 6/e, Elsevier Inc, Philadelphia.

10. Guyton, CA dan Hall, EJ 2014, Buku Ajar Fisiologi Kedokteran, Elsevier. Inc, Singapore.

11. Hoffbrand, AY 2013, Kapita Selekta Hematologi (Essentials Hematology),EGC, Jakarta. 
12. Ikram N, dkk 2014, Ferritin Levels in Patients ofBeta Thalassemia Major,Int J Pathol, Singapore.

13. Kee, JL 2013, Pedoman Pemeriksaan Labarotarium dan Diagnostik, EGC, Jakarta.

14. Johnston, D, Hull, Derek, I 2007, Bayi Baru Lahir, Dalam : Yusna Daulika dan Huriawati Hartanto (eds),Dasar - Dasar Pediatri, EGC, Jakarta.

15. Kartoyo, P dan Purnamawati, SP 2013, Pengaruh Penimbunan Besi TerhadapHati pada Thalassemia. Jurnal, Sari Pediatri Vol.5.

16. Kosasih, EN dan Kosasih, AS 2011, Tafsiran Hasil Pemeriksaan Laboratorium Klinik Edisi ke 2, Kharisma Publishing Group, Jakarta.

17. National Heart, Lung, and Blood Institute Scientific 2011, Statement, Jakarta,

18. USA. Nelson, B 2012, Ilmu Kesehatan Anak,EGC, Jakarta.

19. Notoatmodjo 2010, Metodologi Penelitian Kesehatan, Rineka Cipta, Jakarta.

20. Permono, B,dan Ugrasena, IDG 2012, Hemoglobin: Thalasemia. Dalam: Buku Ajar Hematologi-Onkologi Anak, Ikatan Dokter Anak Indonesia,Jakarta.
21. Sacher, RA dan McPherson, RA 2012, Tinjauan Klinis HasilPemeriksaan Laboratorium, EGC, Jakarta.

22. Saputra, A 2013, Yopie Pangkey, "Pahlawan Darah 4 Lampung" buatPenderita Thalasemia, Harian Kompas, Bandar Lampung.

23. Setiabudy, R, dan Wahidiyat, $P$ 2010 ,Platelet agregation and activation in thalassemia major patients in Indonesia. Clinical Applied Trombosis Hemostasis; Sari Pediatri.

24. Sulaiman, A, dkk(eds) 2011, Buku Ajar Ilmu Penyakit Hati, Sagung Seto, Yogyakarta.

25. Solihin, EA 2016, Jumlah Penderita Thalasemia di RSUAM Capai 120Penderita, Harian Kompas, Bandar Lampung.

26. Soliman,MAE, dkk 2012, Dove Press Journal, Clinical Opthalmology, USA.

27. WHO 2008, Worldwide Prevalence of Thalasemia 1993-2006; WHO GlobalDatabase on Thalasemia, WHO, Geneva.

28. Worwood, M 2007, Iron Metabolism, Iron Deficiensy, and Disorders of HaemSynthesis, Postgraduate Hematology, UK. 